\title{
Spatial variability and potential impacts of climate change on flood and debris flow hazard zone mapping and implications for risk management
}

\author{
H. Staffler ${ }^{1}$, R. Pollinger ${ }^{2}$, A. Zischg ${ }^{3,4}$, and P. Mani $^{5}$ \\ ${ }^{1}$ Department of Civil Protection, Autonomous Province of Bolzano South Tyrol, Bolzano, Italy \\ ${ }^{2}$ Department of Hydraulic Engineering, Autonomous Province of Bolzano South Tyrol, Bolzano, Italy \\ ${ }^{3}$ Abenis AG, Chur, Switzerland \\ ${ }^{4}$ Abenis Alpinexpert srl, Bolzano, Italy \\ ${ }^{5}$ geo7 AG, Berne, Switzerland
}

Received: 18 February 2008 - Revised: 7 May 2008 - Accepted: 13 May 2008 - Published: 12 June 2008

\begin{abstract}
The main goals of this study were to identify the alpine torrent catchments that are sensitive to climatic changes and to assess the robustness of the methods for the elaboration of flood and debris flow hazard zone maps to specific effects of climate changes. In this study, a procedure for the identification and localization of torrent catchments in which the climate scenarios will modify the hazard situation was developed. In two case studies, the impacts of a potential increase of precipitation intensities to the delimited hazard zones were studied.

The identification and localization of the torrent and river catchments, where unfavourable changes in the hazard situation occur, could eliminate speculative and unnecessary measures against the impacts of climate changes like a general enlargement of hazard zones or a general over dimensioning of protection structures for the whole territory. The results showed a high spatial variability of the sensitivity of catchments to climate changes. In sensitive catchments, the sediment management in alpine torrents will meet future challenges due to a higher rate for sediment removal from retention basins. The case studies showed a remarkable increase of the areas affected by floods and debris flow when considering possible future precipitation intensities in hazard mapping. But, the calculated increase in extent of future hazard zones lay within the uncertainty of the methods used today for the delimitation of the hazard zones. Thus, the consideration of the uncertainties laying in the methods for the elab-
\end{abstract}

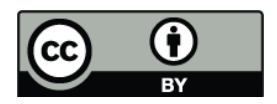

Correspondence to: A. Zischg (a.zischg@abenis.ch) oration of hazard zone maps in the torrent and river catchments sensitive to climate changes would provide a useful instrument for the consideration of potential future climate conditions. The study demonstrated that weak points in protection structures in future will become more important in risk management activities.

\section{Introduction}

The assessment of dangerous processes and the delimitation of hazard zones is a fundamental task in risk analysis and risk management. In general, the assessment and evaluation of geomorphologic processes and hazards could be made using the reconstruction of historical processes (backward directed indication) or using simulation models (forward directed indication, Kienholz et al., 2004). In practice, both approaches mostly are combined. Usually, the hazard assessment is made for the actual state of the studied system (e.g. torrent catchment, landslide area, etc.). Natural hazards are described by the process intensity of a given design event with a certain reoccurrence interval (e.g. 30, 100, 300 years). The actual system status is described by the statistical system behaviour of the last decades.

Due to impacts of climate changes, slight changes in the future system could be assumed. Once changes in the environmental system occurred, the future geomorphologic processes must not occur exactly in the same way as in the past. E.g. shifts in altitude levels or system constellations never observer before could be expected. Thus, backward directed indication of natural hazards and the interpretation

Published by Copernicus Publications on behalf of the European Geosciences Union. 
of the past geomorphologic processes also named as "silent witnesses" and statistical analyses of time series for assessing actual processes will increasingly be subjected to uncertainties. Past observation data (e.g. precipitation data series) could probably not represent the future system status. As a consequence, the statistically described natural hazard situation and the reoccurrence intervals of design flood discharges or design parameters for the planning of hydraulic protection structures could only partially be valid under future climate conditions (e.g. Caspary 1996, 2004, Caspary and Bardossy 1995, Bardossy and Pakosch 2005, Frei et al. 2006, Katzenberger 2004, Hennegriff et al. 2006).

But, most of the decisions made in risk prevention have to be made for a period of almost 30-50 years. E.g. hazard zone maps do influence land use planning over a long period. In Austria or in Switzerland, some of the hazard zone maps made in the 1980ies are still now valid documents for land use planning. Technical construction measures such as river dams or flood retention basins have an average lifespan of almost 50 years. In practice, today's decisions for long-term risk management activities such as the planning of technical protection measures do not consider the future system status but are reactions after damaging events.

Since a few years, the Autonomous Province of Bolzano - South Tyrol, Italy is beginning to elaborate hazard zone maps. Because of the high relevance of the elaborated hazard zone maps for land use planning and the planning of risk reduction measures, the institutions responsible for the elaboration of these decision bases are interested to know, if these documents will be valid also under future climate conditions. Thus, this study aims not at making a contribution to the quantitative assessment of the impacts of climate change to natural hazards. But, the main goal of this study was to assess the robustness or sensitivity of the commonly used procedures for the delimitation of flood and debris flow hazard zone maps to climatic changes. The question should be answered, if, where and how the practices for hazard mapping and risk management must be adapted to potential impacts of climatic changes.

The focus of this case study lied not on the exact representation of the environmental systems by means of detailed process and climate models but on the resulting differences of the hazard assessment representing different climate conditions. Thus, only the potential impacts of climate change to specific input parameters should be studied.

In this study, a procedure

- for identifying the alpine torrent catchments that are sensitive to climatic changes and

- for assessing the robustness of the methods for the elaboration of flood and debris flow hazard zone maps to specific effects of climate changes

should be developed.
The targeted time frame for the assessment of the potential effects of climate changes to the flood risk situation in the Autonomous Province of Bolzano - South Tyrol is the second half of the 21st century (2050-2100). The results of the procedure should lead to formulate recommendations for the adaptation of risk management practices to specific effects of climate changes.

Natural hazards are mostly defined as natural conditions or phenomena which cause undesired consequences for persons, settlements, infrastructures and goods. In some definitions, natural hazards are described as natural geomorphologic processes that are considered as hazards only in intersection with human activities. These processes are characterized as the probability of occurrence of a potentially damaging phenomenon (United Nations, 2004). The physical process itself is characterized by the parameters intensity/magnitude and occurrence probability. The risk resulting from natural hazards is defined as a quantifying function of the probability of occurrence of a dangerous process and the related degree of damage. The latter is specified by the damage potential and the vulnerability of the endangered object (Fuchs et al., 2007).

$R_{i, j}=p_{S i} \cdot A_{O j} \cdot p_{O j, S i} \cdot v_{O j, S i}$

According to the definition of United Nations (2004), the specifications for the probability of the defined scenario $\left(p_{S i}\right)$, the monetary value of the object affected by this scenario $\left(A_{O j}\right)$, the probability of exposure of object $j$ to scenario $i\left(p_{O j, S i}\right)$, and the vulnerability of object $j$ in dependence on scenario $i\left(v_{O j, S i}\right)$ are required for the quantification of risk $\left(R_{i, j}\right)$.

The methods for the description and characterization of the natural hazards in the Alps are based on the intensity and frequency of events. Thus, the concept of the legally binding hazard maps is based on the return period and the intensity of processes. Usually, natural hazards are described in hazard maps by threshold classes of the process intensity for different design events with a given reoccurrence interval (e.g. 30, 100, 300 years, resp. 200 years for rivers with engineering measures). The relative consequences for the land use and the corresponding legally binding restrictions are also based on this concept. Risk analyses are made on the basis of this concept of hazard maps. Furthermore, the planning and design of permanent countermeasures are based on specific design events with a legally defined return period and the related process intensity.

The Autonomous Province Bolzano - South Tyrol adapted the methods for the elaboration of hazard maps of Heinimann et al. (1998) and combined this approach with the Italian national framework legislative of the laws no. 267 of $3 \mathrm{Au}-$ gust 1998, no. 365 of 11 December 2000 and the D.P.C.M. of 29 September 1998 (Gius, 2005). The guidelines for the delimitation of hazard zone maps are described in Gius (2005), Stötter and Zischg (2007) and Autonome Provinz Bozen Südtirol (2006). 
Because of these practices in risk management, the deduction of the most critical factors for hazard assessment under changing environmental conditions is relatively obvious: At least for natural hazards related to precipitation, the most relevant changes in the environmental parameters due to climatic changes are to be expected in the intensity/frequency relation of precipitation events (rainfall, snowfall). Indirect effects are shifts in altitude levels due to rising temperatures, e.g. rising of the altitude of the limit between snowfall and rainfall or rising of the lower boundary of permafrost zones. Seasonal and regional changes in precipitation patterns are to be expected as follows: In Autumn, extreme values for daily precipitations are expected to increase by $10 \%$ in the Northern Alps and by $20 \%$ in the Southern Alps. In winter and spring, an increase between $0 \%$ and $20 \%$ is expected for both regions (KOHS, 2007). Brunetti et al. (2001) observed a trend for an increase in frequency of extreme precipitation events in Northeastern Italy. Under the most unfavourable conditions, a 100-year event of today could in the future become a 20-year event (Frei et al., 2006). Similar trends were calculated for the rivers Donau, Enz, Kocher and Alp in South West Germany (Caspary, 2004). Caspary (2004) underlines that the discharge regimes of these rivers show statistical instationarities in their time series because of the relative accumulation of extreme events since the 1990ies. E.g. a discharge event with a reoccurrence interval of 100 years in the reference period 1932-1976 of the river Enz at the gauge of Pforzheim equals a discharge event with a reoccurrence interval of 30 years in the reference period 1932-2002. Remarkably increases in runoff and discharge volumes were also computed for the Lavanttal region (Austria) when considering possible effects of climate changes (Regional Office of Carinthia, Department of Water Economy 2008).

An indirect effect of the increase of mean temperature is the rising altitude level for the limit between rainfall and snowfall. In areas of the Northern Alps below $1500 \mathrm{~m}$ a.s.l., an increase of flood peaks is expected in winter due to higher soil water contents, the rising of the rainfall/snowfall limit level and due to an increased liquid precipitation (KOHS, 2007). In the pre-Alpine regions, the increase of precipitation in winter and the rising of the snowfall limit will have consequences for the activities of landslides in winter and spring. The increase in saturation leads to an increase in landslide activity and to an increase in sediment load in alpine torrent catchments (Schädler et al., 2007). Due to the rising altitude level of glacier retreat and permafrost degradation, the sediment transport in the areas between approximately 2300 and $2800 \mathrm{~m}$ a.s.l. and with relevant bed load source areas in this altitude level is expected to increase (KOHS, 2007). Since in these areas more precipitation will fall in liquid form, this trend is expected to be remarkably.

Discussions with experts for hazard zone mapping in different workshops resulted, that the following climatological parameters used in the assessment of flood and debris flow hazards are at most sensitive to climate changes
- Intensity of precipitation

- Frequency of precipitation of a certain intensity/magnitude

Other parameters such as the altitude of snowfall limit, the altitude of snowmelt level, the antecedent precipitation, the retreating of glaciers or the degradation of permafrost are considered only in a generalized way in the common procedures for hazard zone mapping. Certain parameters needed for hazard mapping are assumed as worst case scenarios, e.g. the assumption that the altitude of the limit between snowfall and rainfall during extreme precipitation events is higher than the mountain crests and all precipitation contributes to runoff. Thus, in this study only the impacts of a potential increase in the intensities of extreme precipitation events $(>50 \mathrm{~mm} / \mathrm{d})$ to the delimitation of hazard zones were analyzed. On the basis of a literature review, a possible increase in the precipitation intensity of at maximum of $20 \%$ for all design events as indicated by Frei et al. (2006) for the Southern Alps was assumed for this sensitivity analysis. The assumption is consistent with the observed trend in the reduction of the return period between extreme precipitation events in Northeastern Italy (Brunetti et al., 2001). Due to the main focus on the robustness of the procedures for hazard zone mapping, in this study no downscaling procedures from global and regional climate models to the local conditions were followed. It was assumed that the effects of an increase in precipitation intensity of less than $20 \%$ are laying within the uncertainties of the procedures for the delimitation of hazard zones. Therefore, it was expected that an increase of less than $20 \%$ will not show remarkably effects to the increase in the extent of the hazard zones.

\section{Method}

The study was made in three main steps. Firstly, the sensitivity of the alpine torrent catchments to climate changes was analysed qualitatively on the regional scale. Secondly, the possible effects of climate changes to the delimitation of flood hazard zones were analysed in a case study. In another case study, the possible effects of climate changes to the delimitation of debris flow hazard zones were analysed. Finally, conclusions and recommendations for the adaptation of the risk management practices have been elaborated on the basis of the results of the previous three steps.

2.1 Identification and localisation of alpine torrent and river catchments sensitive to climate changes

In this part of the study, the sensitivity of the alpine torrent catchments to climate changes was analysed on the regional scale. The focus of this study lied on the identification of the torrent catchments in which the future climate scenarios 


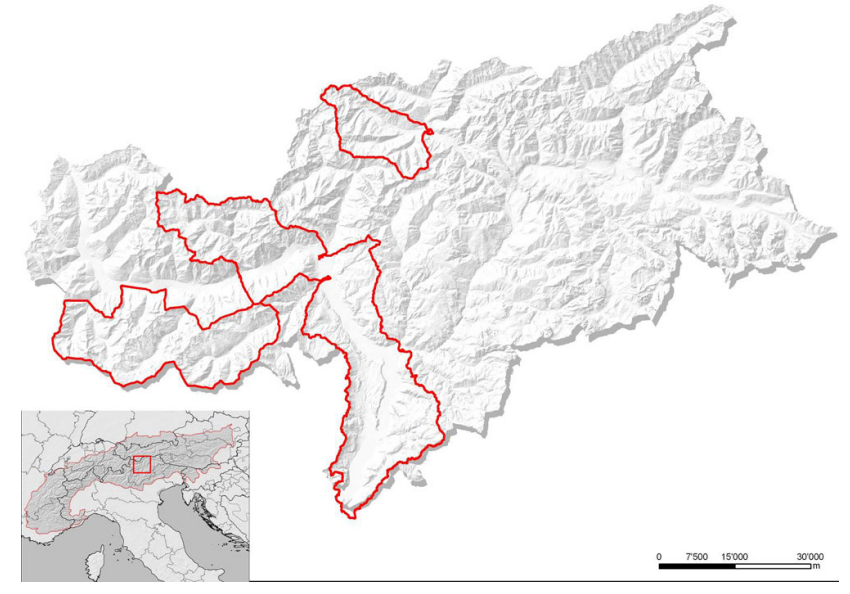

Fig. 1. Study area in the Autonomous Province of Bolzano South Tyrol, Italy.

described above will modify the hazard situation (flood and debris flows).

The first step of the procedure was to match the environmental parameters relevant for hazard assessment on the regional scale with the existing spatial datasets. On the basis of the identified parameters and the existing datasets, an approach for the classification of the torrent catchments of different dimensions and for the qualitative assessment of the sensitivity of the catchments to assumed climatic changes was developed. The catchments were classified into three catchment classes: mountain torrents, torrential rivers and alpine rivers (see Table 1). The results of the study were the delineated catchments classified by the sensitivity to the changes in the selected environmental parameters.

The activities of flood and debris flow processes in alpine torrents are mainly driven by the discharge, the sediment budget and the sediment transport capacity. The sediment transport capacity is influenced either by short precipitation events (thunderstorms) or by longer precipitation events. Because of the steepness of alpine torrent catchments, the hydrological characteristics in the runoff formation are less important. In torrential river catchments both the sediment budget and the hydrological characteristics in the runoff formation are important. In river catchments, the hydrological characteristics in the runoff formation are important. Because of the larger catchment area, the characteristics of the sediment budget are evened.

The sensitivity analysis was made in a pilot area of the Autonomous Province of Bolzano - South Tyrol (Fig. 1). The delimitation of the torrent and river catchments was made on the basis of the classification scheme for public watercourses of the Autonomous Province of Bolzano. The basic assumptions for potential future climate conditions were the following:
- The daily mean temperatures in summer and winter are increasing (Heimann and Sept, 2000; OcCC, 2007)

- The mean sum of precipitation in summer is decreasing or remains constant

- The mean sum of precipitation in winter is increasing (OcCC, 2007)

- The intensity and frequency of short extreme rainfall events in summer and autumn is increasing (Christensen and Christensen, 2003)

It was assumed that the following factors are varying spatially and are relevant for the sensitivity of the torrent catchments to climate changes:

- Percentage of areas located between 1000 and $2000 \mathrm{~m}$ a.s.l.: It is expected that the snow cover in these areas will be reduced and the frequency of combined snowmelt/rainfall events will increase (KOHS, 2006). A threshold value of $50 \%$ of these areas respective to the total catchment area was chosen. This information layer was extracted from the digital elevation model. The value for this parameter was found by a statistical analysis of the catchments assessed as sensitive to climatic changes by local experts.

- Characteristics of bed load source areas: Bed load source areas could be divided into recent and older deposits. Recent deposits are alimented by recent weathering and denudation processes. The quantity of mobilizeable sediment storages in torrents eroding recent deposits is depending on the intensity of the sediment delivery processes and the period between extreme discharge events transporting the weathered material downstream (Zimmermann et al. 1997). Older deposits were composed by relict geomorphologic deposition processes (e.g. glacial moraines, holocene alluvional sediments, landslides). The quantity of mobilizeable sediment storages in torrents eroding older deposits is mainly unlimited. If the percentage of areas with older deposits to the total bed load source area exceeds $30 \%$ of the total catchment area, the torrent catchments were classified as torrents eroding older deposits, otherwise as torrents eroding recent deposits. The value for this parameter was found by a statistical analysis of the catchments assessed as sensitive to climatic changes by local experts. Landslides do influence the quantity of mobilizeable sediment. An increase in precipitation could increase the activity of landslides, especially in winter and spring (Bader and Kunz 1998). If the percentage of landslide areas with respective to the total bed load source area exceeds $30 \%$, the torrent catchments were classified as torrents mainly influenced by landslide activity. This information layer was extracted from the dataset of the hazard index map for debris 
Table 1. Classification of alpine torrent catchments.

\begin{tabular}{lll}
\hline Torrent classification & Catchment area & Description \\
\hline (a) mountain torrents & $<20 \mathrm{~km}^{2}$ & torrents, torrential processes mainly driven by discharge and bed load transport processes \\
(b) torrential rivers & $20-100 \mathrm{~km}^{2}$ & torrential rivers, processes mainly driven by hydrology and partially by bed load transport \\
(c) Alpine rivers & $100-1000 \mathrm{~km}^{2}$ & rivers, processes mainly driven by runoff processes \\
\hline
\end{tabular}

flows and from the landslide inventory of the Geological Survey of the Autonomous Province of Bolzano (IFFI Italian National Landslide Inventory).

- Available bed load source areas: The bed load sediment budget of alpine torrents depends on the quantity of bed load source areas available for sediment transport and the sediment transport capacity. The sensitivity of torrent activity against climate changes increases with a higher proportion of bed load source areas respective to the total catchment area. During the elaboration of the hazard index map for debris flow, the available bed load source areas were computed and weighted on the basis of the relevance for torrential processes (geo7 2006, Heinimann et al. 1998). For this analysis, a minimum threshold for the weighted bed load source areas per catchment was used for the identification of sensitive catchments. This information layer was extracted from the dataset of the hazard index map for debris flows.

- Permafrost degradation and glacier retreat areas: Permafrost influences the hydrology and stability of steep scree slopes, since ice-rich permafrost acts as a barrier to groundwater percolation and can imply local saturation within non-frozen debris (Zimmermann and Haeberli, 1992). Permafrost thawing in non-consolidated material leads to an increase of pore water pressure and a loss of cohesion (Harris et al., 2001). The disappearance of ground ice bodies in scree slopes leaves caverns and destabilizes parts of these disintegrated slope areas. With accelerated permafrost thawing, the susceptibility of these slope areas for landslide and debris flows and the triggered volumes is expected to rise (Zimmermann et al., 1997; Rebetez et al., 1997). Catchments were classified as sensitive, if more than $30 \%$ of the total catchment area is subjected to permafrost degradation. The value for this parameter was found by a statistical analysis of the catchments assessed as sensitive to climatic changes by local experts. This information layer was created by modelling the permafrost distribution of 1850, 1990 and 2100 (after Stötter, 1994; Zischg, 2007). The difference between the datasets of the permafrost distribution of 1850 and 2100 was classified as permafrost degradation areas. Because of a lack in multitemporal glacier datasets, glacier retreat areas were not considered in this study.

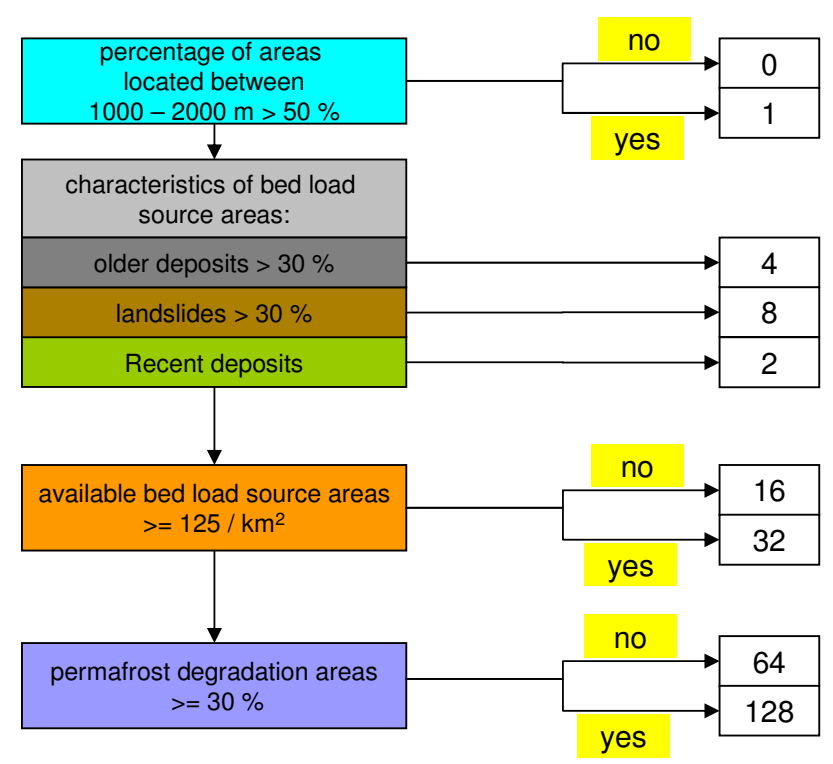

Fig. 2. Decision tree for the identification and localisation of alpine torrent catchments sensitive against climate changes.

- Areas with elevated surface runoff: Areas with reduced water storage capacities increase the surface runoff. The sensitivity of torrential rivers and rivers to climate changes increases with a higher proportion of areas with reduced water storage capacities respective to the total catchments area. This information layer was created by modelling the Topoindex after Beven et al. (1995) under consideration of the geological permeability. This index describes the susceptibility of areas for saturated surface runoff.

The delimitated torrent, torrential river and river catchment areas were classified by the combination of these factors influencing the sensitivity of mountain torrents and rivers to climate changes. The classification was made by means of a decision tree implemented into a GIS-based procedure (Figs. 2, 3, 4). The results of the classification procedure are different classes of torrent and river catchments reacting in different ways to potential climate changes (Figs. 5, 6, 7). The classification of the catchment types are shown in Tables A1-A3. 


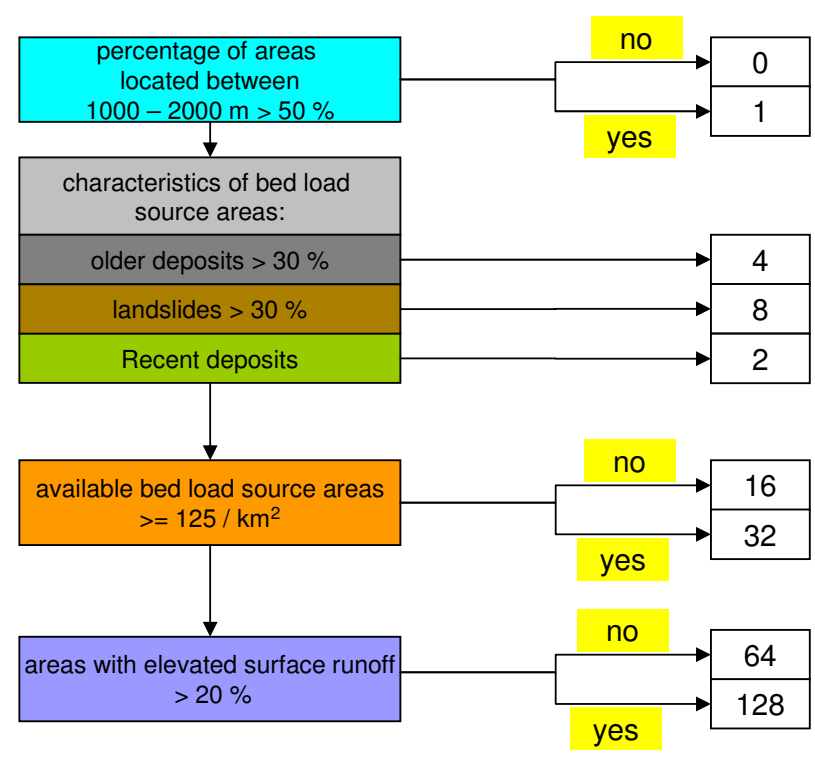

Fig. 3. Decision tree for the identification and localisation of torrential river catchments sensitive against climate changes.

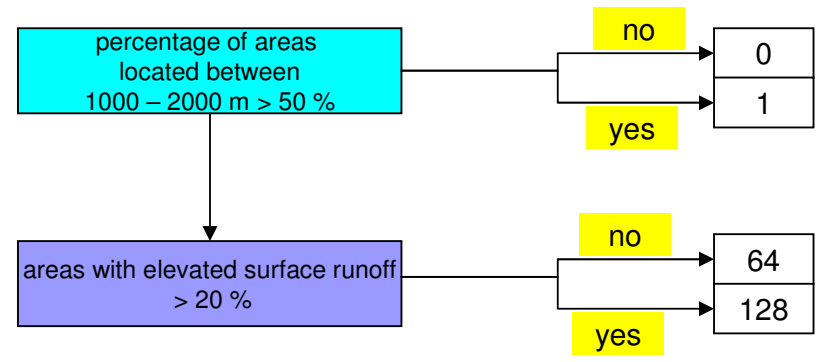

Fig. 4. Decision tree for the identification and localisation of alpine river catchments sensitive against climate changes.

2.2 Potential impacts of climate changes to the delimitation of flood hazard zones, case study Rio Ridanna/Mareiter Bach

In this part of the study, the sensitivity of the common methods and procedures for the delimitation of flood hazard zone maps to climate changes was analysed. The focus of this case study lied not on the exact representation of the environmental systems by means of detailed process and climate models but on testing the robustness of the methods and procedures for hazard mapping to changes of the needed input parameters. On the basis of a literature review, a possible increase of $20 \%$ of the precipitation intensity for each design event (reoccurrence interval 30, 100, 200 years) was assumed for this sensitivity analysis. The hazard induced by bed load transport and overbank sedimentation was not considered.

The Rio Ridanna/Mareiter Bach basin lies in the north of the Autonomous Province of Bolzano - South Tyrol (Fig. 8). The river endangers parts of the Vipiteno/Sterzing Basin and

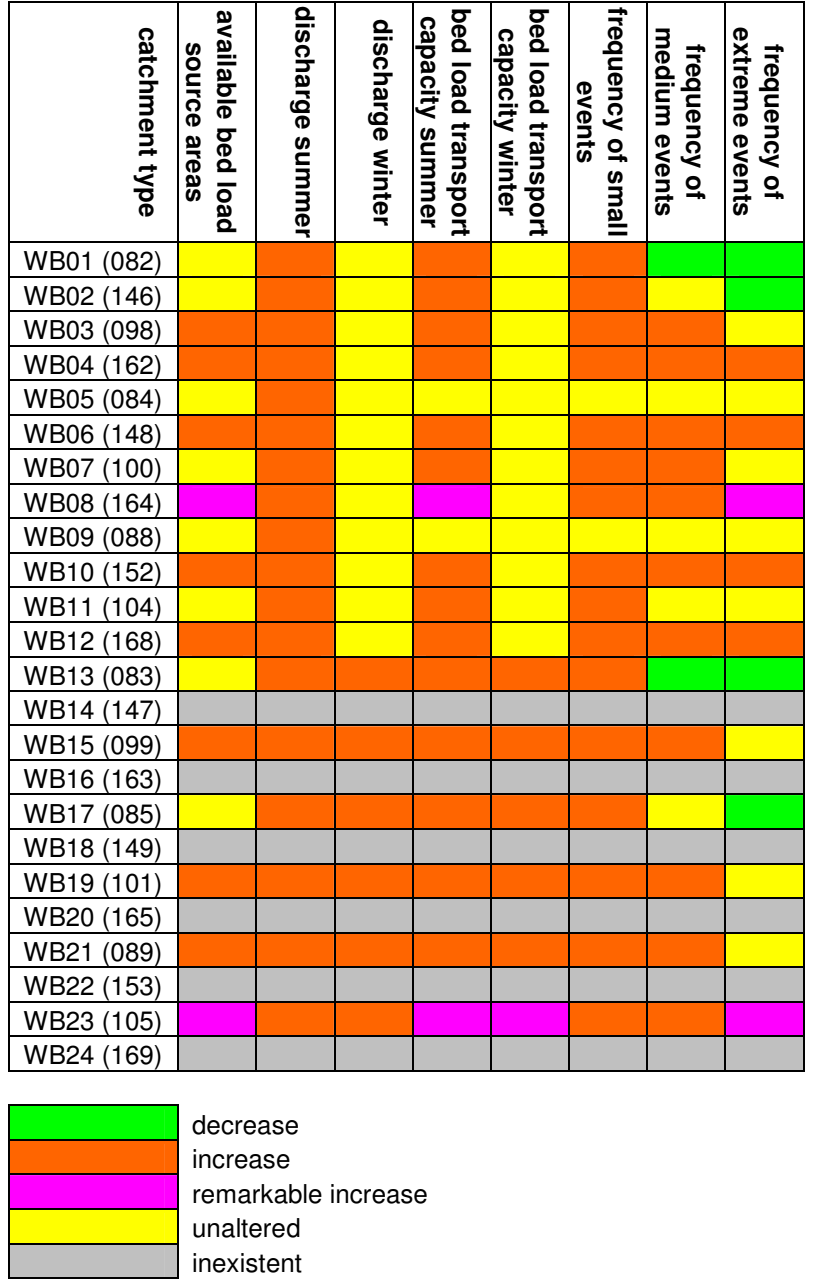

Fig. 5. Synthesis of the considered potential impacts of climate changes to alpine torrent catchments (WB01 to WB24). The identification number of the torrent catchment type resulting from the decision tree is shown in the brackets

the city of Vipiteno/Sterzing and confluences with the Isarco/Eisack River. The catchment area is $210 \mathrm{~km}^{2}$. This study area is a representative example for an alpine river with hazard potential for settlements.

For the assessment of the present flood hazard situation of the Rio Ridanna/Mareiter Bach for the Vipiteno/Sterzing basin, this procedure was followed:

- statistical analyses of the precipitation time series of the measurement stations in the study area and calculation of the characteristics of precipitation events relevant for the hazard scenarios with a return period of 30,100 and 200 years,

- preparation and calibration of the rainfall-runoff model,

- simulation of the inundation processes for each return period, 


\begin{tabular}{|c|c|c|c|c|c|c|c|c|}
\hline 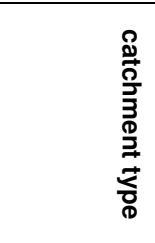 & 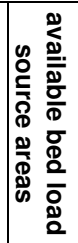 & 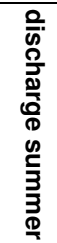 & 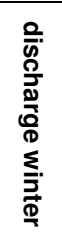 & 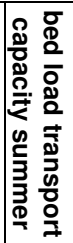 & 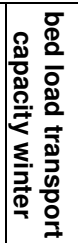 & 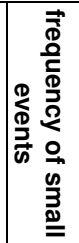 & 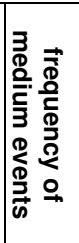 & 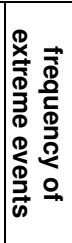 \\
\hline \multicolumn{9}{|l|}{ WF01 (082) } \\
\hline \multicolumn{9}{|l|}{ WF02 (146) } \\
\hline \multicolumn{9}{|l|}{ WF03 (098) } \\
\hline \multicolumn{9}{|l|}{ WF04 (162) } \\
\hline \multicolumn{9}{|l|}{ WF05 (084) } \\
\hline \multicolumn{9}{|l|}{ WF06 (148) } \\
\hline \multicolumn{9}{|l|}{ WF07 (100) } \\
\hline \multicolumn{9}{|l|}{ WF08 (164) } \\
\hline \multicolumn{9}{|l|}{ WF09 (088) } \\
\hline \multicolumn{9}{|l|}{ WF10 (152) } \\
\hline \multicolumn{9}{|l|}{ WF11 (104) } \\
\hline \multicolumn{9}{|l|}{ WF12 (168) } \\
\hline \multicolumn{9}{|l|}{ WF13 (083) } \\
\hline \multicolumn{9}{|l|}{ WF14 (147) } \\
\hline \multicolumn{9}{|l|}{ WF15 (099) } \\
\hline \multicolumn{9}{|l|}{ WF16 (163) } \\
\hline \multicolumn{9}{|l|}{ WF17 (085) } \\
\hline \multicolumn{9}{|l|}{ WF18 (149) } \\
\hline \multicolumn{9}{|l|}{ WF19 (101) } \\
\hline \multicolumn{9}{|l|}{ WF20 (165) } \\
\hline \multicolumn{9}{|l|}{ WF21 (089) } \\
\hline \multicolumn{9}{|l|}{ WF22 (153) } \\
\hline \multicolumn{9}{|l|}{ WF23 (105) } \\
\hline WF24 (169) & & & & & & & & \\
\hline
\end{tabular}

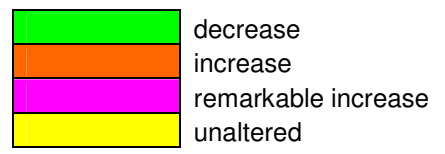

Fig. 6. Synthesis of the considered potential impacts of climate changes to torrential river catchments (WF01 to WF24). The identification number of the torrential river catchment type resulting from the decision tree is shown in the brackets.

- delimitation of the hazard zone map,

- analysis of the exposed buildings.

The results of the procedures described above were the hazard maps describing the hazard situation on the basis of simplified assumptions representing present (scenario 2000) and future (2050-2100) climate conditions (scenario $+20 \%$ ). The main focus laid more on the comparison of the two hazard situations rather than on the single hazard assessment itself.

The statistical analysis of the precipitation time series was based on the measurement stations of Ridanna/Ridnaun ( 31 measurement years). In the analysis, precipitation events with a duration of $24 \mathrm{~h}$ were considered (Scherer and Mazzorana, 2007). The calculated precipitation values of a rainfall event with a duration of 24 hours representing reoccurrence intervals of 30, 100 and 200 years are shown in Table 2. For the representation of the design precipitation events under

\begin{tabular}{|c|c|c|c|c|c|c|c|c|}
\hline 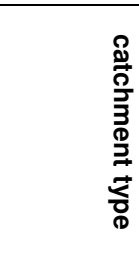 & 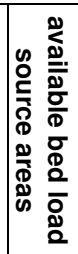 & 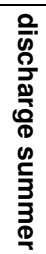 & 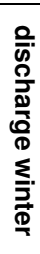 & 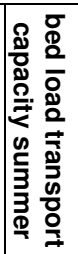 & 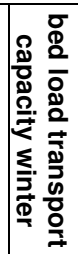 & 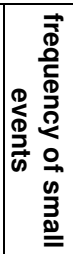 & 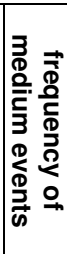 & 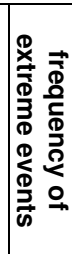 \\
\hline \multicolumn{9}{|l|}{ FL01 (064) } \\
\hline \multicolumn{9}{|l|}{ FL02 (128) } \\
\hline \multicolumn{9}{|l|}{ FL03 (065) } \\
\hline FL04 (129) & & & & & & & & \\
\hline
\end{tabular}

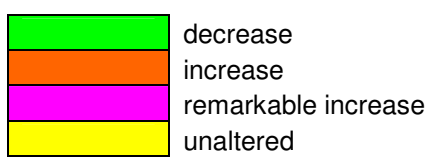

Fig. 7. Synthesis of the considered potential impacts of climate changes to alpine river catchments (FL01 to FL04). The identification number of the river catchment type resulting from the decision tree is shown in the brackets.

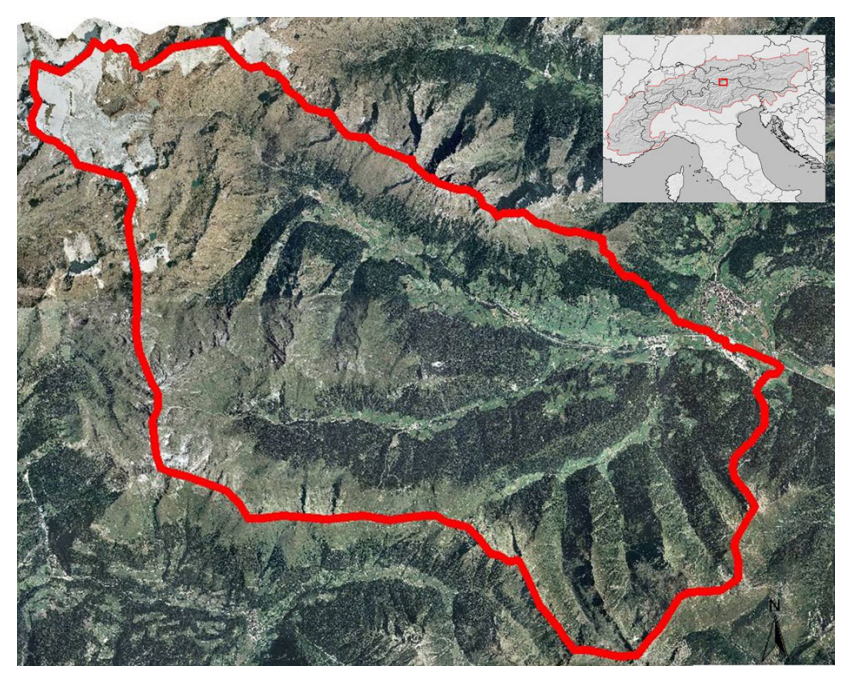

Fig. 8. Localisation and delimitation of the Rio Ridanna/Mareiter Bach catchment.

future climate conditions (scenario $+20 \%$ ) $20 \%$ of these calculated values were added (see Table 2). For the discharge prediction, the rainfall-runoff model Hec-HMS and the SCSapproach was used and adapted to the catchment characteristics of the Rio Ridanna/Mareiter Bach. The calibration of the model was made within the Interreg IIIB project "River Basin Agenda" (Scherer and Mazzorana, 2005a; Scherer and Mazzorana, 2005b). The model was calibrated with the precipitation events of 1996 and 1997. For the simulation of the inundation process, the simulation model SOBEK of WL Delft Hydraulics was used. The flood hazard zone map was made by following the guidelines for hazard zone mapping of the Autonomous Province of Bolzano - South Tyrol (Autonome Provinz Bozen - Südtirol, 2006) and Heinimann et 
Table 2. Calculated rainfall and runoff values for relevant return periods and different climate conditions (Scherer and Mazzorana, 2007).

\begin{tabular}{ccccc}
\hline \multirow{2}{*}{ return period of a rainfall event, duration $24 \mathrm{~h}$} & $\mathrm{~N}_{\text {tot }}$ (precipitation) $[\mathrm{mm}]$ & Qmax $($ discharge) & at confluence $\left[\mathrm{m}^{3} / \mathrm{s}\right]$ \\
\cline { 2 - 5 } & scenario 2000 & scenario $+20 \%$ & scenario 2000 & scenario $+20 \%$ \\
30 years & 106.6 & 127.9 & 212.5 & 299.6 \\
100 years & 125.7 & 150.8 & 272.6 & 383.9 \\
200 years & 136.6 & 164.0 & 333.3 & 431.8 \\
\hline
\end{tabular}

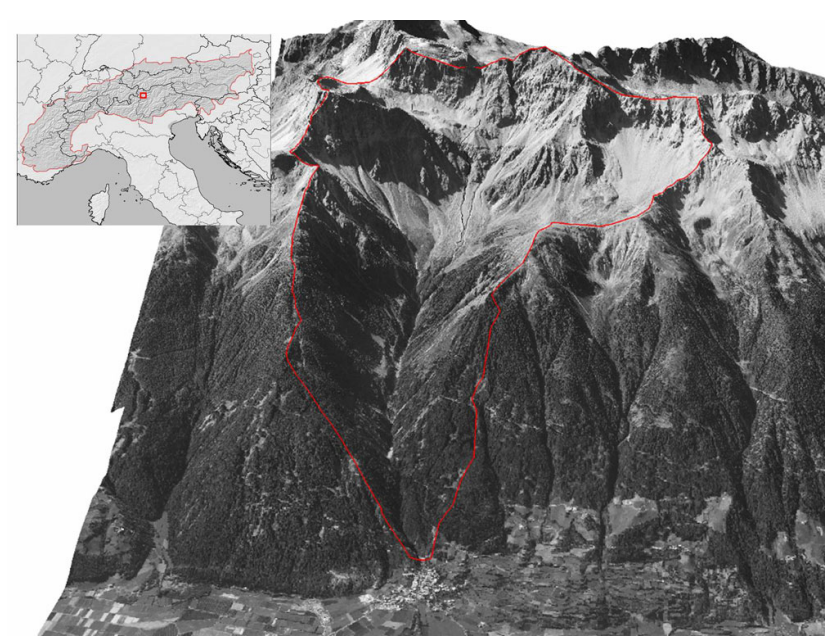

Fig. 9. Localisation and delimitation of the Rio Cengles/Tschenglser Bach catchment.

al. (1998). The resulting hazard maps were overlayed with the buildings in the settlement areas. Thus, the changes in the hazard situation were demonstrated by the changes in the extent of the hazard zones and by the changes in the number of the endangered buildings. The related damages were estimated by multiplying the number of endangered buildings with a mean value of expected losses per building. This value represents a combination of the terms $\mathrm{A}_{O j}$ and $\mathrm{v}_{O j, S i}$ in Eq. 1. For residential buildings, a mean value of expected losses of about $€ 45000$ was used, and for industry buildings a mean value of expected losses of about $€ 80000$ was used for the estimation of the potential damages regarding flood events.

2.3 Potential impacts of climate changes to the delimitation of debris flow hazard zones, case study Rio Cengles/Tschenglser Bach

The Rio Cengles/Tschenglser Bach torrent lies in the western part of the Autonomous Province of Bolzano South Tyrol. The Rio Cengles/Tschenglser Bach torrent confluences with the river Adige/Etsch. The catchment area is $11 \mathrm{~km}^{2}$. This study area is a representative example for systematized alpine torrents eroding older deposits in permafrost degradation ar- eas (Fig. 9). The hazard potential of these kinds of torrents is mainly driven by the sediment mobilization and bedload transport capacity because of the unlimited sediment source areas. The sediment transport capacity is driven by the runoff and the discharge. The upper catchment area is characterized by the disappearance of a small glacier in the recent years and the erosion of oversteepened scree slopes supposed to permafrost degradation. The Rio Cengles/Tschenglser Bach is systematised by sediment retention basins and check dams.

For the assessment of the actual situation of debris flow hazards in the Rio Cengles/Tschenglser Bach catchment, the following procedure was followed (IPP 2007):

- characteristics of precipitation events relevant for the hazard scenarios with a return period of 30, 100 and 300 years,

- preparation and verification of the rainfall-runoff model,

- simulation of the bed load transport in the transit area and in the sediment retention basins,

- simulation of the debris flow processes in the deposition area for each return period,

- delimitation of the hazard zone map,

- analysis of the exposed buildings.

Since no meteorological station is located in the catchment area or in the neighbourhood of $20 \mathrm{~km}$, the calculation of the rainfall characteristics representing the present climate conditions (scenario 2000) was made following the procedures of VAPI (Valutazione delle portate in Italia, Villi and Bacchi 2001). Villi and Bacchi (2001) made a regionalization of the precipitation intensities for given reoccurrence intervals. The results of the procedure were the needed input parameters for the hydrologic and hydraulic simulations representing precipitation events with reoccurrence intervals of 30 , 100 and 300 years and a duration of 1 hour (scenario 2000, see Table 5). Because of the steepness of the catchment, intensive rainfall events with a duration of one hour are the most relevant precipitation scenarios. These values fit with the values of the precipitation time series of the meteorological station in Prato/Prad. For the representation of future 
climate conditions (scenario $+20 \%$ ), $20 \%$ of these precipitation values were added (IPP, 2007; Table 5). For the discharge prediction, the rainfall-runoff model Hec-HMS and the SCS-approach was used and adapted to the catchment characteristics of the Rio Cengles/Tschenglser Bach. The calibration of the model was made with well documented debris flow events (Gostner, 2002). For the simulation of the bed load transport in the transit area and in the sediment retention basins, the simulation model DAMBRK of the US National Weather Service was used. For the simulation of the debris flow processes in the runout area, the simulation model Flow-2D (O'Brian, 2001) was used. The flood hazard zone map was made following the guidelines for hazard zone mapping of the Autonomous Province of Bolzano - South Tyrol (Autonome Provinz Bozen - Südtirol, 2006) and Heinimann et al. (1998).

\section{Results}

3.1 Identification and localisation of alpine torrent and river catchments sensitive to climate changes

The main results of the procedure were the classification of the torrent catchments into different reaction typologies and the classification into different sensitivity typologies (Fig. 10). The datasets could be queried under different aspects. Figure 10 show a high spatial variability of the sensitivity of the torrent catchments to specific impacts of climatic changes. This underlines the observations made in the Ecrin massif (Jomelli et al., 2004; Jomelli et al., 2007). The procedure was made also for torrential river and river catchments. The results showed that the runoff of nearly all torrent catchments is expected to increase in summer (Fig. 10a). The runoff in winter is expected to increase only in torrent catchments having a high percentage of their total surface area below $2000 \mathrm{~m}$ (Fig. 10b). The bed load transport in summer is expected to increase in high mountain areas and is expected to decrease in catchments at submontane levels (Fig. 10c). In some catchments eroding younger deposits (weathered material), a decrease in extreme events is highlighted (Fig. 10f). This is consistent with the observations of Jomelli et al. (2004), Jomelli et al. (2007) and Stoffel and Beniston (2006). In some catchments eroding older deposits an increase in extreme events is pointed out (Fig. 10f). This seems consistent with the observations of Rebetez et al. (1997). The bed load transport in winter increases in a few mountain torrent catchments and does not change in the most catchments (Fig. 10d). The frequency of small scale debris flow and sediment transport processes is expected to increase in most of the torrent catchments (Fig. 10e).
Table 3. Number of buildings endangered by flood processes of the Rio Ridanna/Mareiter Bach and per hazard zones.

\begin{tabular}{ccccc}
\hline \multirow{2}{*}{ hazard zone } & \multicolumn{4}{c}{ number of exposed buildings } \\
\cline { 2 - 5 } & \multicolumn{2}{c}{ scenario 2000} & \multicolumn{2}{c}{ scenario $+20 \%$} \\
\hline habitation & production & habitation & production \\
yellow & 12 & 30 & 13 & 6 \\
blue & 3 & 7 & 9 & 35 \\
red & 0 & 1 & 2 & 2 \\
\hline
\end{tabular}

3.2 Potential impacts of climate changes to the delimitation of flood hazard zones, case study Rio Ridanna/Mareiter Bach

By increasing the rainfall intensities for the design events describing the basic assumptions for the delimitation of the hazard zone maps by $20 \%$, the parameters needed for hazard evaluation changed as shown in Table 2. Figure 11 show the spatial changes of the inundation processes. The modelling results (flow depth and flow velocity) were classified following the guidelines for hazard zone mapping of the Autonomous Province of Bolzano - South Tyrol (Autonome Provinz Bozen - Südtirol, 2006) and Heinimann et al. (1998). Figure 12 shows the impacts of climate changes to the delimitation of the compiled hazard zone maps (synthesis of all design events) by considering flow depth and flow velocity without further on-site investigations.

The study confirmed the results of prior analyses that the discharge capacity of the Rio Ridanna/Mareiter Bach in the Vipiteno/Sterzing basin is lower than the discharge of a design event with a return period of 30 years. Either considering the effects of climate changes to the hazard situation or not, this fact leads to the endangerment of parts of the Vipiteno/Sterzing basin also during relatively frequent events. The historical analyses of flooding events in the Vipiteno/Sterzing basin confirmed this fact (Zischg, 2005).

The analyses of the possible impacts of climate changes showed that the flooded areas of a design event with a return period of 30 years representing the assumed future climate conditions (scenario $+20 \%$ ) have a larger extent than the flooded areas of a design event with a return period of 100 years representing the actual climate conditions (scenario 2000). The hazard zones delimited and classified following the guidelines for hazard zone mappings show remarkable changes if considering the assumed changes in precipitation intensities due to climate changes. The hazard zones representing the assumed future climate conditions show a shift from the yellow zones to the blue zones. In this case study, the extent of the blue zones increased significantly. The changes in the extent of the hazard zones implicate changes in the number of exposed buildings (see Table 3). Under the assumptions made in this study, the buildings exposed to 


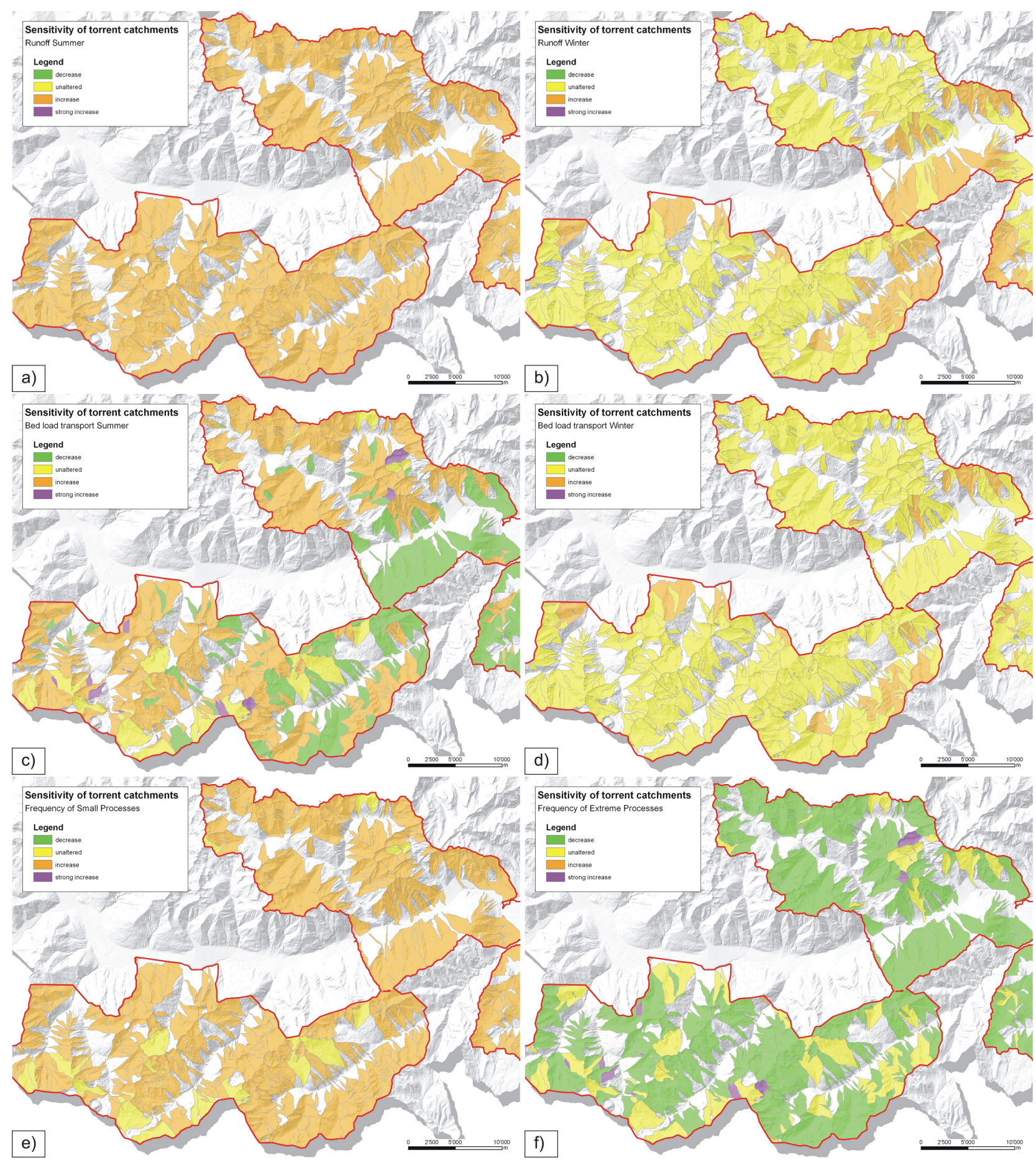

Fig. 10. Classified torrent catchments and their qualitative sensitivity to the assumed changes in the environmental parameters influencing the hazard situation. (a) Sensitivity of torrent catchments to climate changes: Runoff in summer. (b) Runoff in winter. (c) Bed load transport in summer. (d) Bed load transport in winter. (e) Frequency of small scale processes. (f) Frequency of extreme events. 

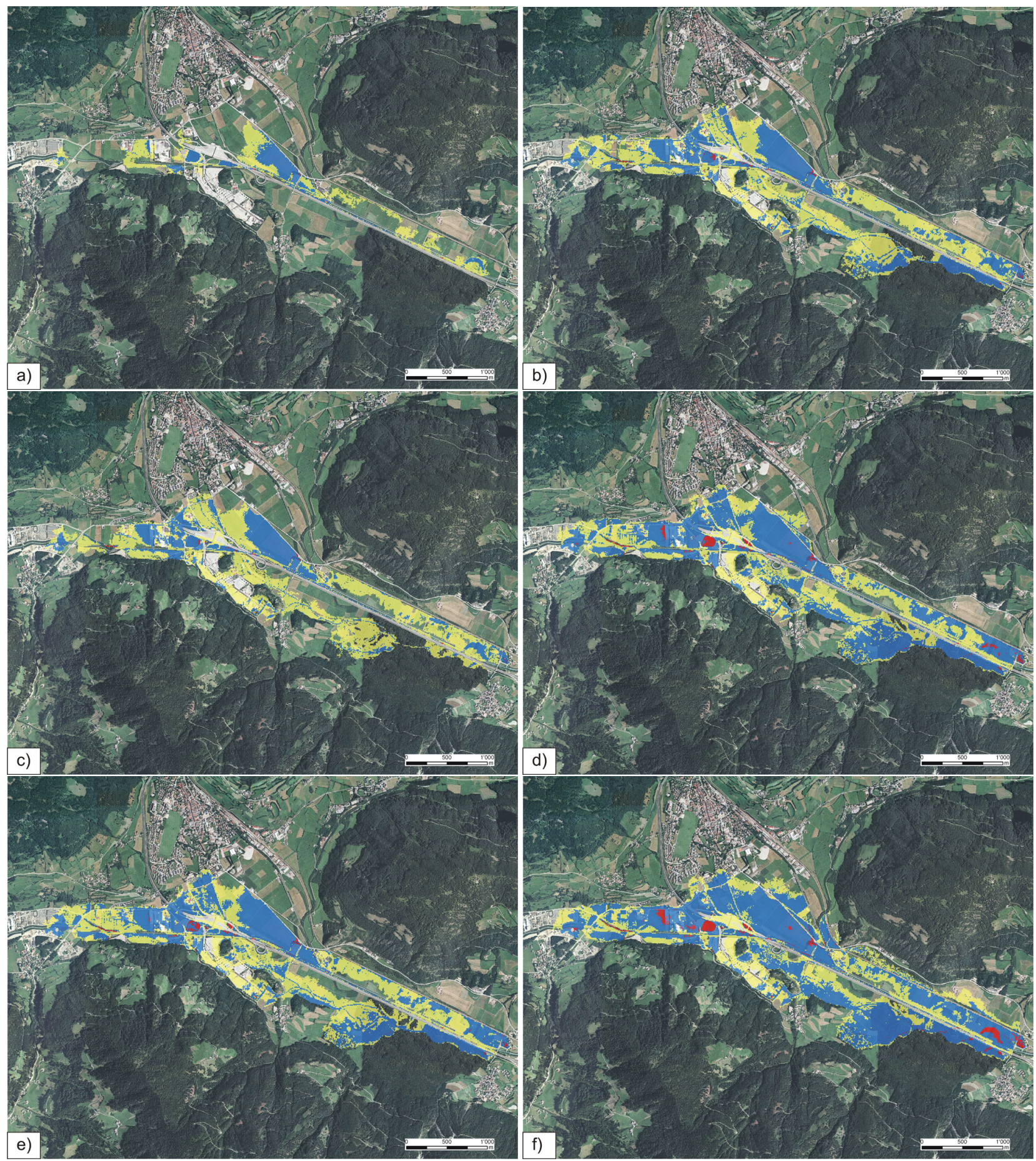

Fig. 11. Changes in flow depths and affected area of the inundation process in the Vipiteno/Sterzing basin. The maps show the classified flow depth. Flow depths from 0 to $0.5 \mathrm{~m}$ are shown in yellow, flow depths from 0.5 to $2 \mathrm{~m}$ are shown in blue, flow depths of more than $2 \mathrm{~m}$ are shown in red. (a) Flooded area of a discharge with a return period of 30 years (HQ30) representing scenario 2000. (b) Flooded area of a discharge with a return period of 30 years (HQ30) representing scenario $+20 \%$. (c) Flooded area of a discharge with a return period of 100 years (HQ100) representing scenario 2000. (d) Flooded area of a discharge with a return period of 1000 years (HQ100) representing scenario $+20 \%$. (e) Flooded area of a discharge with a return period of 200 years (HQ200) representing scenario 2000. (f) Flooded area of a discharge with a return period of 200 years (HQ200) representing scenario $+20 \%$. 

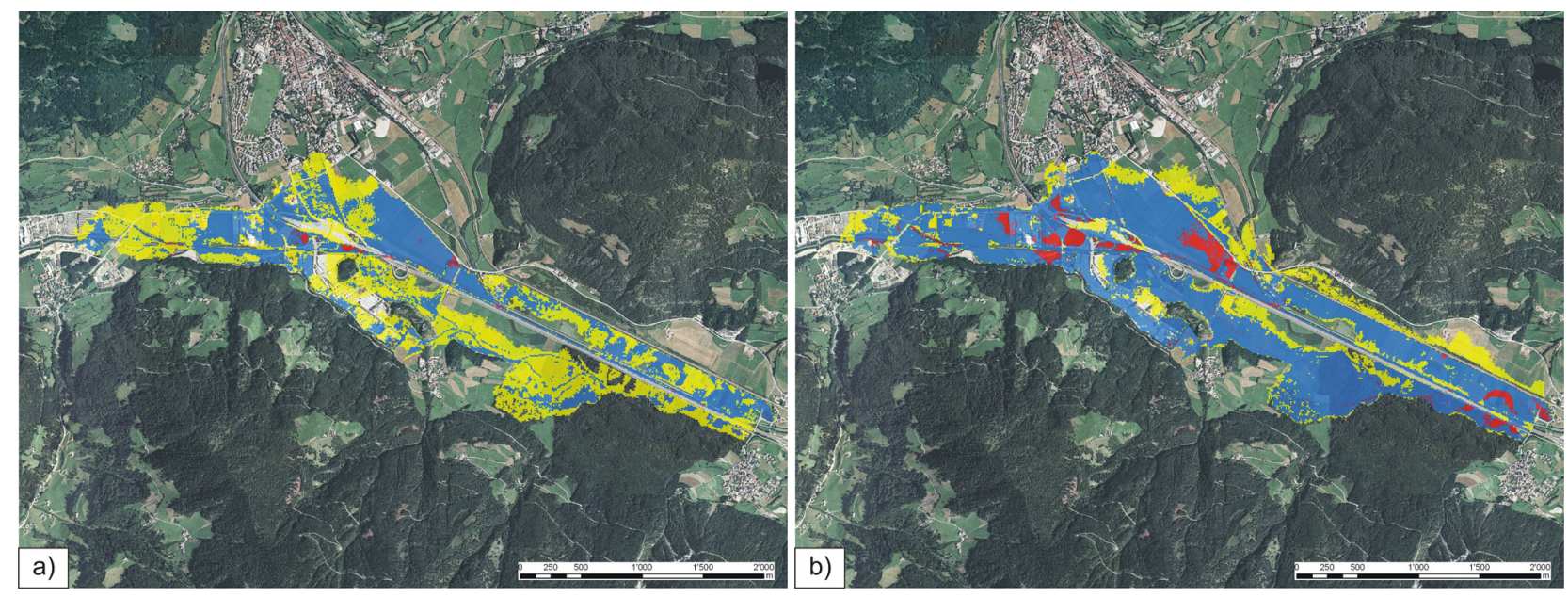

Fig. 12. Results of inundation modelling reclassified following the guidelines for hazard zone mapping (Autonome Provinz Bozen - Südtirol 2006; in red hazard zones, the construction of new buildings is restricted; in blue hazard zones, the construction of new buildings is regulated; in yellow hazard zones prevail hazards with low intensities). (a) Flood hazard map representing scenario 2000. (b) Flood hazard map representing scenario $+20 \%$.

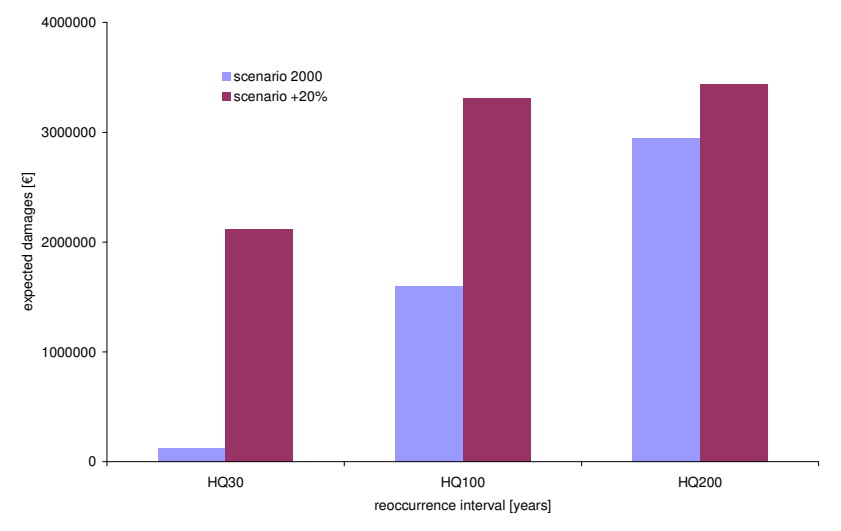

Fig. 13. Changes in expected damages due to flood events in the Vipiteno/Sterzing Basin for the scenario representing the present climate conditions and for the scenario representing possible future climate conditions.

flood hazards with a low intensity (yellow hazard zones) in future may be exposed to blue hazard zones. This is valid especially for the industrial buildings constructed during the last decade in the free spaces in the neighbourhood of the rivers, avoided for settlement in the decades before. The potential shifts from blue hazard zones to red hazard zones do not show significant consequences for buildings. The related risks increased for each scenario (Table 4 and Fig. 13). The expected damages of a flood event with a return period of 30 years (scenario $+20 \%$ ) increased up to $1700 \%$ (in comparison to the scenario 2000). The expected damages of a flood event with a return period of 100 years increased up to $207 \%$ and up to $117 \%$ for an event with a return period of 200 years.
3.3 Potential impacts of climate changes to the delimitation of debris flow hazard zones, case study Rio Cengles/Tschenglser Bach

By increasing the rainfall intensities for the design rainfall events for the delimitation of the hazard zone maps of $20 \%$, the parameters needed for hazard evaluation changed as shown in Table 5. The assumed increase of $20 \%$ of the input parameter rainfall intensity for the design events (scenario $+20 \%$ ) lead to an increase of the water discharge of about $37 \%$ for a return period of 30 years, of about $45 \%$ for a return period of 100 years and of about $31 \%$ for a return period of 300 years. The transported volumes increased about $36 \%$ for a return period of 30 years, about $51 \%$ for a return period of 100 years and of about $43 \%$ for a return period of 300 years relative to the design events representing the actual climate conditions. The peak discharge of a design event with a return period of 30 years representing the assumed future climate conditions has nearly the same dimension as a design event with a return period of 100 years representing the actual climate conditions (Table 5). The areas affected by debris flows increases of about $4-30 \%$ if the assumed future climate conditions are considered in the simulation model (Fig. 14). The changes in the extent of the hazard zones do not have consequences for the settlements and do not influence the risk situation (if the case of an occlusion of the channel in the settlement area due to wood debris etc. and resulting overflow of the river banks is not considered). 
Table 4. Number of buildings endangered by flood processes of the Rio Ridanna/Mareiter Bach and expected damages per design events.

\begin{tabular}{ccccccc}
\hline \multirow{2}{*}{ reoccurrence interval } & \multicolumn{5}{c}{ number of exposed buildings and related damages } \\
\cline { 2 - 6 } & habitation & production & damages $[€]$ & habitation & production & damages [€] \\
& 1 & 1 & 125000 & 8 & 22 & 2120000 \\
30 & 7 & 16 & 1595000 & 13 & 34 & 3305000 \\
100 & 12 & 30 & 2940000 & 16 & 34 & 3440000 \\
\hline
\end{tabular}

Table 5. Calculated rainfall and runoff values and bed load transport in the Rio Cengles/Tschenglser Bach torrent for relevant return periods and different climate conditions (IPP, 2007).

\begin{tabular}{|c|c|c|c|c|c|c|}
\hline \multirow{2}{*}{ return period of a rainfall event, duration $60 \mathrm{~min}$} & \multicolumn{2}{|c|}{$\mathrm{N}_{\text {tot }}$ (precipitation) $[\mathrm{mm}]$} & \multicolumn{2}{|c|}{$\mathrm{Q}_{\max }($ discharge $)$ at confluence $\left[\mathrm{m}^{3} / \mathrm{s}\right]$} & \multicolumn{2}{|c|}{ VB (volume of transported material) $\left[\mathrm{m}^{3}\right]$} \\
\hline & scenario 2000 & scenario $+20 \%$ & scenario 2000 & scenario $+20 \%$ & scenario 2000 & scenario $+20 \%$ \\
\hline 30 years & 55.6 & 66.7 & 31.5 & 44.4 & 59000 & 80000 \\
\hline 100 years & 74.2 & 89.0 & 47.3 & 70.4 & 73000 & 110000 \\
\hline 300 years & 81.2 & 97.5 & 63.5 & 86.5 & 83000 & 119000 \\
\hline
\end{tabular}

\section{Conclusions}

The results of the approach for assessing and classifying the sensitivity of mountain torrent and torrential river catchments against the assumed climate changes showed where the future scenarios of natural hazards are expected to occur more likely. The analyses pointed out that the impacts of climate changes to the hazard situation of torrential and river systems have a high spatial variability. The identification and localization of the torrent catchments, where unfavourable changes in the hazard situation occur could eliminate speculative and unnecessary measures against the impacts of climate changes like a general enlargement of hazard zones or a general over dimensioning of protection structures for the whole territory (e.g. as suggested by Hennegriff et al., 2006). Thus, the procedure could support the discussion about future strategies for adaptation to alternated climate conditions by providing the trends for the development of the hazard situation in a higher spatial resolution.

At the moment, the procedure for the identification and localization of torrent catchments does not consider quantitatively future climate scenarios (e.g. global and regional climate models). This weakness in fact could be eliminated in future, but the qualitative approach allows the transfer of the approach to other areas. The dataset about the classified torrent and torrential river catchments and their sensitivity to climate changes provides the basis for the identification and localization of settlement areas, where increases in the future risk potential have to be expected.

As an example for the use of the dataset, the hazard index map for debris flow processes (geo7, 2006; Zimmermann et al., 1997) was overlaid with the sensitive catchments and the settlement areas. The intersection of these two databases leads to the identification and localisation of potential debris flow processes starting in catchments that are sensitive to changes due to permafrost degradation. The settlement areas potentially affected by these debris flow processes were pointed out. The potential debris flow processes starting in catchments that are sensitive to permafrost degradation are endangering only insignificant parts of the settlements in the Autonomous Province of Bolzano. Thus, only these settlement areas are sensitive to this specific impact of climate change. But, the environmental changes in the starting areas of the debris flows endangering these sensitive areas must be observed and monitored.

The procedure for the identification and localisation of alpine torrent and torrential river catchments that are sensitive to climate changes provide an information basis for the identification of these cases, where the risk potential tends to increase. Because the impacts of climate changes to natural hazards show remarkably regional differences, the knowledge about where the expected changes in the natural hazard situation have consequences to the risk situation is crucial for the consideration of the impacts of climate change in land use planning and risk management. The presented procedure provides a further information basis for decisionmaking in land use planning and natural hazard and risk management with a long-term planning horizon. Furthermore, it provides a methodological framework for further refinement and enhancement of the consideration of the effects of climate changes in natural hazards and risk management.

The case study of the Rio Ridanna/Mareiter Bach river showed possible consequences of climate changes to the hazard situation of an alpine river. The study showed that the assumed increase of the precipitation intensities has 


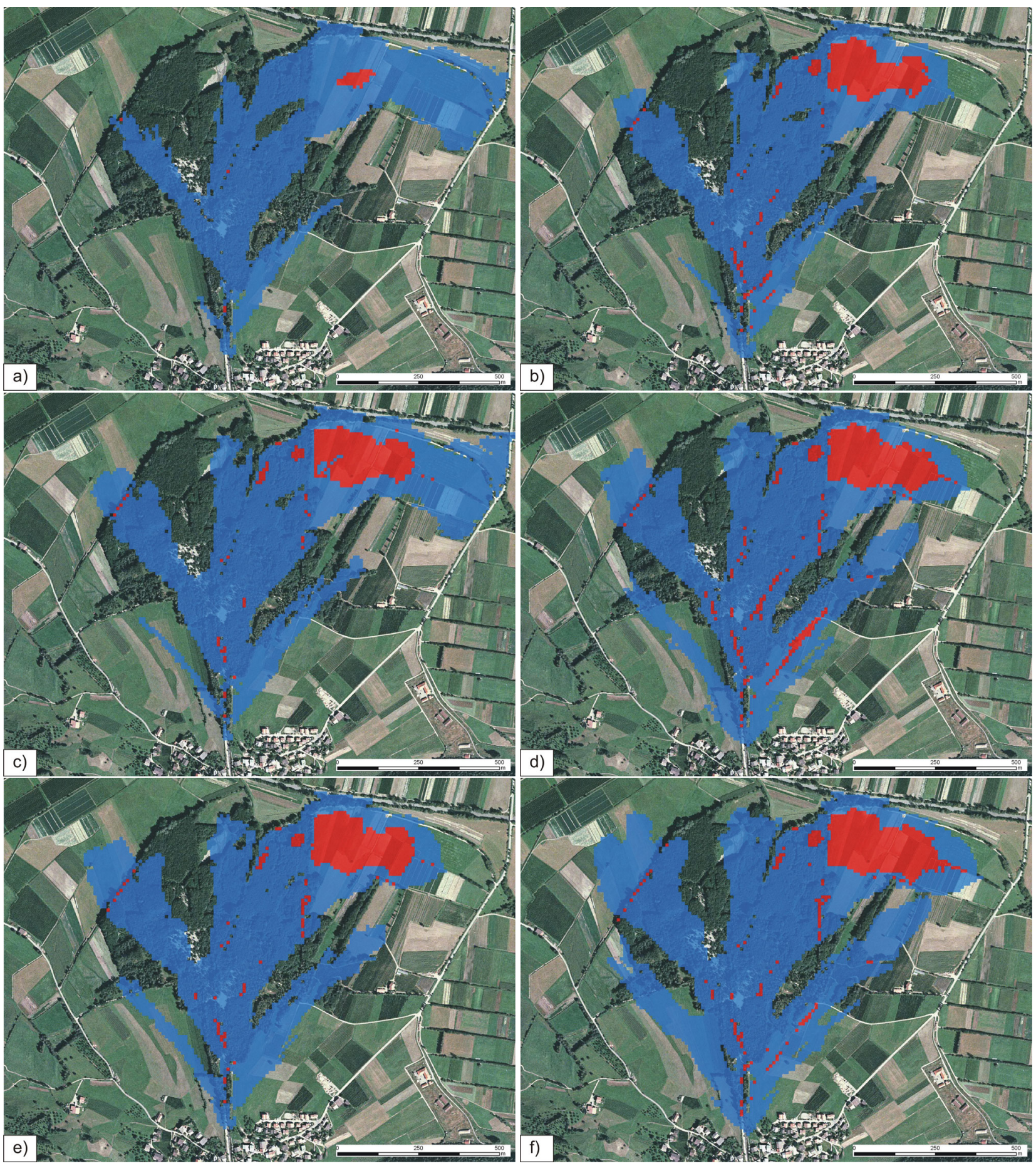

Fig. 14. Changes in flow depths and affected area of the debris flow processes of the Rio Cengles/Tschenglser Bach torrent. The maps show the classified flow depth following the guidelines for hazard zone mapping (Autonome Provinz Bozen - Südtirol, 2006). Flow depths from 0 to $1 \mathrm{~m}$ are shown in blue, flow depths greater than $1 \mathrm{~m}$ are shown in red. Critical shear stress parameter of $400 \mathrm{~Pa}$. (a) Flow depths for a design event with a return period of 30 years (scenario 2000). (b) Flow depths for a design event with a return period of 30 years (scenario $+20 \%$ ). (c) Flow depths for a design event with a return period of 100 years (scenario 2000). (d) Flow depths for a design event with a return period of 100 years (scenario $+20 \%$ ). (e) Flow depths for a design event with a return period of 300 years (scenario 2000). (f) Flow depths for a design event with a return period of 300 years (scenario $+20 \%)$. 


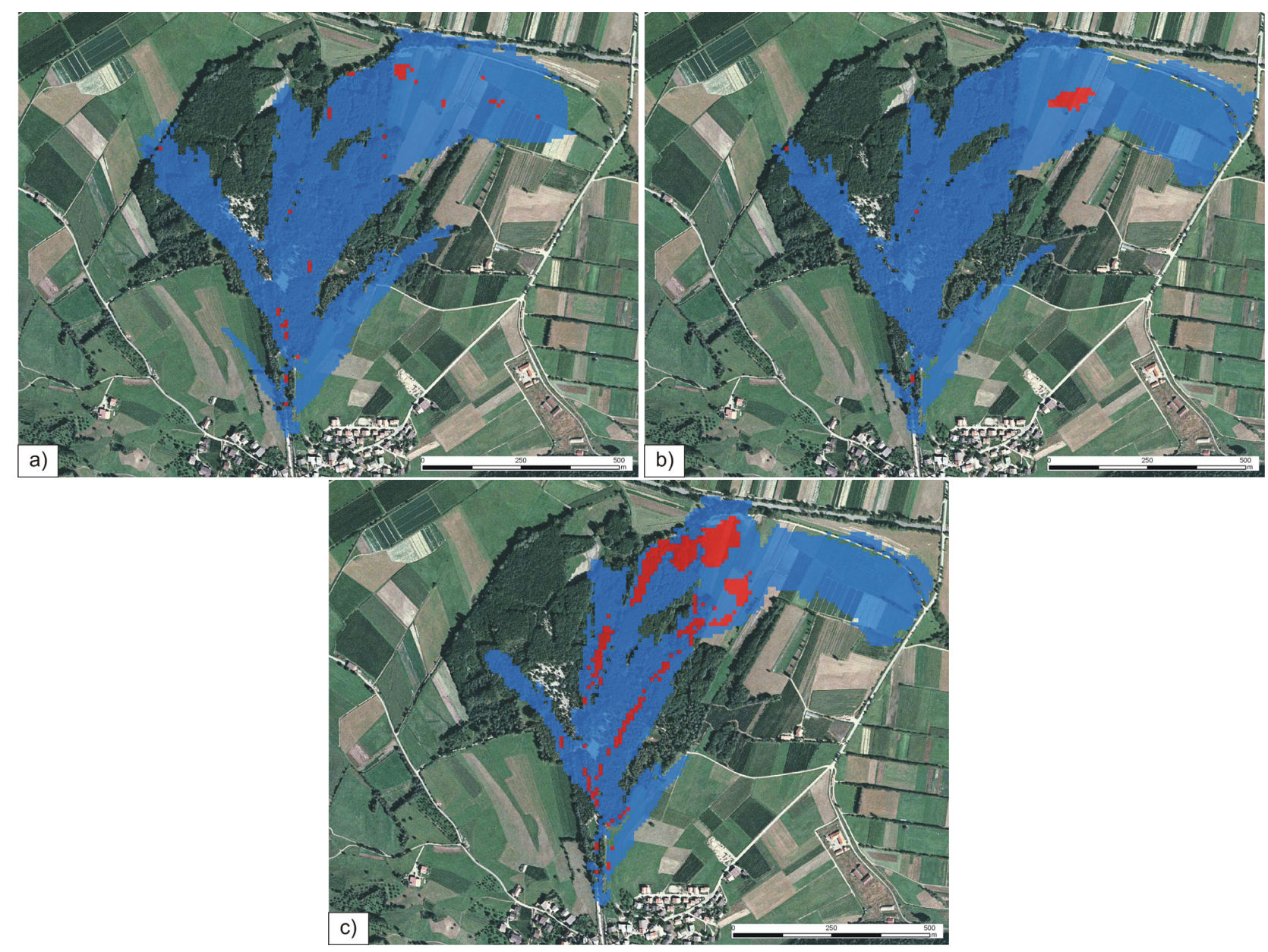

Fig. 15. Variations in flow depth and extent of a design event with a return period of 30 years (actual climate conditions) using different input parameters for the critical shear stress. (a) Flow depths for a design event with a return period of 30 years (scenario 2000). Critical shear stress parameter of $200 \mathrm{~Pa}$. (b) Flow depths for a design event with a return period of 30 years (scenario 2000). Critical shear stress parameter of $400 \mathrm{~Pa}$. (c) Flow depths for a design event with a return period of 30 years (scenario 2000). Critical shear stress parameter of $800 \mathrm{~Pa}$.

remarkable impacts on the natural hazard situation (process intensities). The calculated increase of discharge due to the assumed increase in rainfall intensity showed a significant accentuation of the already existing weak points in the protection structures and the resulting hazard situation. The modelling results showed a remarkably increase in the flooded areas and an increase in flow depths. The hazard zones changed one "level" of hazard classification. Generally, the "yellow" zones delineated on the basis of the actual climate conditions tended to become "blue" zone. This could lead to significant restrictions for land use. The study demonstrated that already known weak points in risk reduction systems as protection structures in future will become more important in risk management activities. This means that the stress-strain behaviour of these weak points in cases of discharges exceeding the channel capacity must be stud- ied. The knowledge about the behaviour of protection structures in loading case could provide a decision base for the elaboration of and the training of crisis management plans.

The potential effects of changed input parameters as the precipitation intensity to the extent of the hazard zones are not negligible for land use planning purposes. Usually, the hazard assessment of floods is based on the statistical analysis of relatively short data series for precipitation and discharge measurements. As shown in this case study, the analysis of the flood processes bases on a data series of about 31 years. Because of the curtness of the available data series, the calculated intensity values for the future design rainfall event $(+20 \%)$ representing the future climate conditions (2050-2100) are laying within the 95\% confidence interval of the data series representing the present climate conditions. Thus, the assumed future changes in the input 
parameter "precipitation intensity" lay within the uncertainty of the methods used today for the delimitation of the hazard zones. Thus, the consideration of the uncertainties laying in the methods used for the elaboration of hazard zone maps would provide a useful instrument for the consideration of potential future climate conditions in sensitive catchments.

The case study of the Rio Cengles/Tschenglser Bach torrent confirmed the hypothesis that the bed load transport capacity of torrents eroding older deposits increases with a potential increase in rainfall intensity. Due to the unlimited predisposition of mobilizeable material for debris flows, the process intensity of these torrents increases with the increase of bed load transport capacity because of higher discharges. The changes in process intensity in the deposition area of the debris flow are remarkable, but are lying within the uncertainties due to mostly poorly known process characteristics and models. The ranges of the modelling results due to changes in the input parameters of rheology and critical shear stresses of the debris flow simulation model exceed the ranges of the modelling results due to changes in the input parameter for rainfall intensity (Fig. 15).

The case study showed that possible effects of climate changes are not relevant for torrents that have been systemized with remarkably efforts and where the runout and deposition areas of the torrential processes have been kept free from settlements and infrastructures. Nevertheless, the analyses showed that an assumed increase of rainfall intensity lead to a nonlinear increase of the process intensities. Especially the volume transported by debris flows due to the increase in discharge and transport capacity increased remarkably when considering possible future climate conditions.
This lead to the conclusion that the sediment management in alpine torrents will meet future challenges. In future, the costs for maintenance of existing protection structures will increase due to higher deposition volumes and a higher frequency of removal of debris flow deposits from sediment retention basins. Thus, cost-benefit analyses made within the planning of new protection structures must consider the future higher operating expenses.

The study showed that an increase in the intensity and frequency of flood and debris flow hazards has to be expected as a consequence of climate changes in sensitive catchments. But, the effects of these changes in the hazard situation to the risk situation depend also on other factors in the risk equation. The future changes in the extent of the damage potential and the vulnerability of endangered objects to natural hazard processes would also influence the future risk potential. Thus, the consideration of impacts of climate changes in natural hazard and risk management must be made using a holistic approach combining all the available instruments and possibilities from risk prevention to land use planning and crisis management activities.

The conceptional approach for assessing the impacts of climate changes on risks showed that especially the factor of the vulnerability mostly unconsidered in risk analyses points out the uncertainties in this assessment. But, the consideration of this risk factor opens new possibilities for risk reduction. With the reduction of the vulnerability of endangered buildings against the dangerous processes, a remarkable increase in the hazard potential as an impact of climate changes must not stringently conduct in an increase in risk. 


\section{Appendix A}

Table A1. Types of Alpine torrent catchments.

\begin{tabular}{|c|c|c|}
\hline $\begin{array}{l}\text { catchment } \\
\text { type }\end{array}$ & $\begin{array}{l}\text { ID } \\
\text { decision } \\
\text { tree }\end{array}$ & Description \\
\hline WB01 & 082 & Higher located mountain torrent catchments with minor bed load source areas, mainly recent deposits. \\
\hline WB02 & 146 & $\begin{array}{l}\text { Higher located mountain torrent catchments with minor bed load source areas, mainly recent deposits. } \\
\text { Important areas affected by permafrost degradation or glacier retreat. }\end{array}$ \\
\hline WB03 & 098 & Higher located mountain torrent catchments with major bed load source areas, mainly recent deposits. \\
\hline WB04 & 162 & $\begin{array}{l}\text { Higher located mountain torrent catchments with major bed load source areas, mainly recent deposits. } \\
\text { Important areas affected by permafrost degradation or glacier retreat. }\end{array}$ \\
\hline WB05 & 084 & Higher located mountain torrent catchments with minor bed load source areas, manly older deposits. \\
\hline WB06 & 148 & $\begin{array}{l}\text { Higher located mountain torrent catchments with minor bed load source areas, manly older deposits. } \\
\text { Important areas affected by permafrost degradation or glacier retreat. }\end{array}$ \\
\hline WB07 & 100 & Higher located mountain torrent catchments with major bed load source areas, manly older deposits. \\
\hline WB08 & 164 & $\begin{array}{l}\text { Higher located mountain torrent catchments with major bed load source areas, manly older deposits. } \\
\text { Important areas affected by permafrost degradation or glacier retreat. }\end{array}$ \\
\hline WB09 & 088 & Higher located mountain torrent catchments with minor bed load source areas and active landslides. \\
\hline WB10 & 152 & $\begin{array}{l}\text { Higher located mountain torrent catchments with minor bed load source areas and active landslides. } \\
\text { Important areas affected by permafrost degradation or glacier retreat. }\end{array}$ \\
\hline WB11 & 104 & Higher located mountain torrent catchments with major bed load source areas and active landslides. \\
\hline WB12 & 168 & $\begin{array}{l}\text { Higher located mountain torrent catchments with major bed load source areas and active landslides. } \\
\text { Important areas affected by permafrost degradation or glacier retreat. }\end{array}$ \\
\hline WB13 & 083 & Lower located mountain torrent catchments with minor bed load source areas, mainly recent deposits. \\
\hline WB14 & 147 & $\begin{array}{l}\text { Lower located mountain torrent catchments with minor bed load source areas, mainly recent deposits. } \\
\text { Important areas affected by permafrost degradation or glacier retreat. Not existing! }\end{array}$ \\
\hline WB15 & 099 & Lower located mountain torrent catchments with major bed load source areas, mainly recent deposits. \\
\hline WB16 & 163 & $\begin{array}{l}\text { Lower located mountain torrent catchments with major bed load source areas, mainly recent deposits. } \\
\text { Important areas affected by permafrost degradation or glacier retreat. Not existing! }\end{array}$ \\
\hline WB17 & 085 & Lower located mountain torrent catchments with minor bed load source areas, manly older deposits. \\
\hline WB18 & 149 & $\begin{array}{l}\text { Lower located mountain torrent catchments with minor bed load source areas, manly older deposits. } \\
\text { Important areas affected by permafrost degradation or glacier retreat. Not existing! }\end{array}$ \\
\hline WB19 & 101 & Lower located mountain torrent catchments with major bed load source areas, manly older deposits. \\
\hline WB20 & 165 & $\begin{array}{l}\text { Lower located mountain torrent catchments with major bed load source areas, manly older deposits. } \\
\text { Important areas affected by permafrost degradation or glacier retreat. Not existing! }\end{array}$ \\
\hline WB21 & 089 & Lower located mountain torrent catchments with minor bed load source areas and active landslides. \\
\hline WB22 & 153 & $\begin{array}{l}\text { Lower located mountain torrent catchments with minor bed load source areas and active landslides. } \\
\text { Important areas affected by permafrost degradation or glacier retreat. Not existing! }\end{array}$ \\
\hline WB23 & 105 & Lower located mountain torrent catchments with major bed load source areas and active landslides. \\
\hline WB24 & 169 & $\begin{array}{l}\text { Lower located mountain torrent catchments with major bed load source areas and active landslides. } \\
\text { Important areas affected by permafrost degradation or glacier retreat. Not existing! }\end{array}$ \\
\hline
\end{tabular}


Table A2. Types of torrential river catchments.

\begin{tabular}{|c|c|c|}
\hline $\begin{array}{l}\text { catchment } \\
\text { type }\end{array}$ & $\begin{array}{l}\text { ID } \\
\text { decision } \\
\text { tree }\end{array}$ & Description \\
\hline WF01 & 082 & $\begin{array}{l}\text { Higher located torrential river catchments with minor bed load source areas, mainly recent deposits. } \\
\text { Limited susceptibility to surface runoff. }\end{array}$ \\
\hline WF02 & 146 & $\begin{array}{l}\text { Higher located torrential river catchments with minor bed load source areas, mainly recent deposits. } \\
\text { Increased susceptibility to surface runoff. }\end{array}$ \\
\hline WF03 & 098 & $\begin{array}{l}\text { Higher located torrential river catchments with major bed load source areas, mainly recent deposits. } \\
\text { Limited susceptibility to surface runoff }\end{array}$ \\
\hline WF04 & 162 & $\begin{array}{l}\text { Higher located torrential river catchments with major bed load source areas, mainly recent deposits. } \\
\text { Increased susceptibility to surface runoff. }\end{array}$ \\
\hline WF05 & 084 & $\begin{array}{l}\text { Higher located torrential river catchments with minor bed load source areas, mainly older deposits. } \\
\text { Limited susceptibility to surface runoff }\end{array}$ \\
\hline WF06 & 148 & $\begin{array}{l}\text { Higher located torrential river catchments with minor bed load source areas, mainly older deposits. } \\
\text { Increased susceptibility to surface runoff. }\end{array}$ \\
\hline WF07 & 100 & $\begin{array}{l}\text { Higher located torrential river catchments with major bed load source areas, mainly older deposits. } \\
\text { Limited susceptibility to surface runoff }\end{array}$ \\
\hline WF08 & 164 & $\begin{array}{l}\text { Higher located torrential river catchments with major bed load source areas, mainly older deposits. } \\
\text { Increased susceptibility to surface runoff. }\end{array}$ \\
\hline WF09 & 088 & $\begin{array}{l}\text { Higher located torrential river catchments with minor bed load source areas and active landslides. } \\
\text { Limited susceptibility to surface runoff }\end{array}$ \\
\hline WF10 & 152 & $\begin{array}{l}\text { Higher located torrential river catchments with minor bed load source areas and active landslides. } \\
\text { Increased susceptibility to surface runoff. }\end{array}$ \\
\hline WF11 & 104 & $\begin{array}{l}\text { Higher located torrential river catchments with major bed load source areas and active landslides. } \\
\text { Limited susceptibility to surface runoff }\end{array}$ \\
\hline WF12 & 168 & $\begin{array}{l}\text { Higher located torrential river catchments with major bed load source areas and active landslides. } \\
\text { Increased susceptibility to surface runoff. }\end{array}$ \\
\hline WF13 & 083 & $\begin{array}{l}\text { Lower located torrential river catchments with minor bed load source areas, mainly recent deposits. } \\
\text { Limited susceptibility to surface runoff. }\end{array}$ \\
\hline WF14 & 147 & $\begin{array}{l}\text { Lower located torrential river catchments with minor bed load source areas, mainly recent deposits. } \\
\text { Increased susceptibility to surface runoff. }\end{array}$ \\
\hline WF15 & 099 & $\begin{array}{l}\text { Lower located torrential river catchments with major bed load source areas, mainly recent deposits. } \\
\text { Limited susceptibility to surface runoff }\end{array}$ \\
\hline WF16 & 163 & $\begin{array}{l}\text { Lower located torrential river catchments with major bed load source areas, mainly recent deposits. } \\
\text { Increased susceptibility to surface runoff. }\end{array}$ \\
\hline WF17 & 085 & $\begin{array}{l}\text { Lower located torrential river catchments with minor bed load source areas, mainly older deposits. } \\
\text { Limited susceptibility to surface runoff }\end{array}$ \\
\hline WF18 & 149 & $\begin{array}{l}\text { Lower located torrential river catchments with minor bed load source areas, mainly older deposits. } \\
\text { Increased susceptibility to surface runoff. }\end{array}$ \\
\hline WF19 & 101 & $\begin{array}{l}\text { Lower located torrential river catchments with major bed load source areas, mainly older deposits. } \\
\text { Limited susceptibility to surface runoff }\end{array}$ \\
\hline WF20 & 165 & $\begin{array}{l}\text { Lower located torrential river catchments with major bed load source areas, mainly older deposits. } \\
\text { Increased susceptibility to surface runoff. }\end{array}$ \\
\hline WF21 & 089 & $\begin{array}{l}\text { Lower located torrential river catchments with minor bed load source areas and active landslides. } \\
\text { Limited susceptibility to surface runoff }\end{array}$ \\
\hline WF22 & 153 & $\begin{array}{l}\text { Lower located torrential river catchments with minor bed load source areas and active landslides. } \\
\text { Increased susceptibility to surface runoff. }\end{array}$ \\
\hline WF23 & 105 & $\begin{array}{l}\text { Lower located torrential river catchments with major bed load source areas and active landslides. } \\
\text { Limited susceptibility to surface runoff }\end{array}$ \\
\hline WF24 & 169 & $\begin{array}{l}\text { Lower located torrential river catchments with major bed load source areas and active landslides. } \\
\text { Increased susceptibility to surface runoff. }\end{array}$ \\
\hline
\end{tabular}


Table A3. Types of river catchments.

\begin{tabular}{lll}
\hline $\begin{array}{l}\text { catchment } \\
\text { type }\end{array}$ & $\begin{array}{l}\text { ID } \\
\text { decision } \\
\text { tree }\end{array}$ & Description \\
\hline FL01 & & $\begin{array}{l}\text { Higher located alpine river catchments. Limited susceptibility to surface runoff. } \\
\text { FL02 }\end{array}$ \\
FL04 & Higher located alpine river catchments. Increased susceptibility to surface runoff. \\
FL02 & Lower located alpine river catchments. Limited susceptibility to surface runoff. \\
\hline
\end{tabular}

Acknowledgements. The project was co-financed by the European Union within the Interreg IIIB Alpine Space project "ClimChAlp Climate Change, Impacts and Adaptation strategies for the Alps". The authors thank to C. Scherer and B. Mazzorana for the simulation of the flood processes, A. Waldner and W. Gostner for modelling the debris flow processes and M. Eschgfäller for the literature review. Furthermore, the authors thank to V. Jomelli and another anonymous referee for their constructive remarks.

Edited by: F. Castelli

Reviewed by: V. Jomelli and another anonymous referee

\section{References}

Autonome Provinz Bozen - Südtirol: Richtlinien für die Erstellung von Gefahrenzonenplänen und zur Klassifizierung des spezifischen Risikos, Bozen, 2006.

Bader, S. and Kunz, P.: Klimarisiken - Herausforderung für die Schweiz, Zurich, 1998.

Bardossy, A. and Pakosch, S.: Wahrscheinlichkeiten extremer Hochwasser unter sich ändernden Klimaverhältnissen, Wasserwirtschaft, 97, 58-64, 2005.

Beven, K. J., Lamb, R., Quinn, P., Romanowicz, R., and Freer, J.: TOPMODEL. In: Computer Models of Watershed Hydrology, edited by: Singh, V. P., Water Resources Publications, 1995.

Brunetti, M., Maugeri, M., and Nanni, T.: Changes in total precipitation, rainy days and extreme events in northeastern Italy, Pure and Applied Geophysics, 21, 861-871, 2001.

Caspary, H. J.: Recent winter floods in Germany caused by changes in the atmosperic circulation across Europe, Physics and Chemistry of the Earth, 20, 459-462, 1996.

Caspary, H. J.: Zunahme "kritischer" Wetterlagen als Ursache für die Entstehung extremer Hochwasser in Südwestdeutschland, in: Klimaveränderung und Konsequenzen für die Wasserwirtschaft - Fachvorträge beim KLIWA-Symposium am 3. und 4.5.2004 in Würzburg, 135-151, 2004.

Caspary, H. J. and Bardossy, A.: Markieren die Winterhochwasser 1990 und 1993 das Ende der Stationarität in der Hochwasserhydrologie infolge Klimaänderungen? Wasser \& Boden, 47, 18-24, 1995.

Christensen, J. H. and Christensen, O. B.: Climate modelling: Severe summertime flooding in Europe, Nature, 421, 805-806, 2003.
Frei, C., Schöll, R., Fukutome, S., Schmidli, J., and Vidale, P. L.: Future change of precipitation extremes in Europe: Intercomparison of scenarios from regional climate models, J. Geophys. Res., 111, D06105, doi:10.1029/2005JD005965, 2006.

Fuchs, S., Heiss, K., and Hübl, J.: Towards an empirical vulnerability function for use in debris flow risk assessment. Nat. Hazards Earth Syst. Sci., 7, 495-506, 2007, http://www.nat-hazards-earth-syst-sci.net/7/495/2007/.

geo7: Gefahrenhinweiskarte Murgang und Übersarung. Technischer Bericht. Unpublished project report within the Interreg IIIA Italy-Switzerland project "Entwicklung und Anwendung eines Systems zur überregionalen Erkennung und Bewertung hydrogeologischer Risiken”, Bozen, 27 pp., 2006.

geo7: Gefahrenhinweiskarte Murgang und Übersarung: Auswertung im Hinblick auf die Klimaänderung. Erläuterungen zum Entscheidungsbaum, Unpublished report within the project Interreg IIIB Alpine Space "ClimChAlp - Climate Change, Impacts and Adaptation Strategies in the Alpine Space", Bozen, 34 pp., 2007.

Gius, S.: Die Gefahrenzonenplanung in Südtirol, Wildbach- und Lawinenverbau 152, 49-61, 2005.

Gostner, W.: Integrale Analyse eines murfähigen Wildbaches anhand einer Fallstudie. Unpublished M.S. thesis, ETH Lausanne, Lausanne, 203 pp., 2002.

Harris, C., Davies, M. C. R., and Etzelmüller, B.: The assessment of potential geotechnical hazards associated with mountain permafrost in a warming global climate. Permafrost Periglac., 12, 145-156, 2001.

Heimann, D. and Sept, V.: Climate change estimates of summer temperature and precipitation in the Alpine region. Theor. Appl. Climatol., 66, 1-12, 2000.

Heinimann, H., Hollenstein, K., Kienholz, H., Krummenacher, B., and Mani, P.: Methoden zur Analyse und Bewertung von Naturgefahren. Umweltmaterialen Bundesamt für Umwelt, Wald und Landschaft, Bern, 249 pp., 1998.

Hennegriff, W., Kolokotronis, V., Weber, H., and Bartels, H.: Klimawandel und Hochwasser. Erkenntnisse und Anpassungsstrategien beim Hochwasserschutz. Wasser, Abfall, 53, 770-779, 2006.

IPP Ingenieure Patscheider and Partner GmbH: Untersuchungen zur Sensitivität der Murganggefahr des Tschenglser Baches gegenüber möglichen Klimaveränderungen. Unpublished report within the project Interreg IIIB Alpine Space "ClimChAlp - Climate Change, Impacts and Adaptation Strategies in the Alpine Space", Bozen, 2007.

Jomelli, V., Pech, V., Chochillon, C., and Brunstein, D.: Geomor- 
phic Variations of Debris Flows and Recent Climatic Change in the French Alps, Climatic Change, 64(1), 77-102, 2004.

Jomelli, V., Brunstein, D., Grancher, D., and Pech, P.: Is the response of hill slope debris flows to recent climate change univocal? A case study in the Massif des Ecrins (French Alps), Climatic Change, 85(1), 119-137, 2007.

Katzenberger, B.: Bisherige Erkenntnisse aus KLIWA - Handlungsempfehlungen. In: KLIWA, (ed.): Klimaveränderung und Konsequenzen für die Wasserwirtschaft - Fachvorträge beim KLIWA-Symposium am 3 und 4 Mai 2004 in Würzburg, 197204, 2004

Kienholz, H., Krummenacher, B., Kipfer, A., and Perret, S.: Aspects of integral risk management in practice - Considerations with respect to mountain hazards in Switzerlands, Österreichische Wasser- und Abfallwirtschaft, 3-4, 43-50, 2004.

KOHS - Kommission Hochwasserschutz im Schweizerischen Wasserwirtschaftsverband: Auswirkungen der Klimaänderung auf den Hochwasserschutz in der Schweiz. Ein Standortpapier der Kommission Hochwasserschutz im Schweizerischen Wasserwirtschaftsverband (KOHS), Wasser, Energie, Luft, 99(1), 5559, 2007.

O'Brien, J. S. and Julien, P. Y.: FLO-2D, Users Manual, Version 2001.06, 2001.

OcCC: Klimaänderung und die Schweiz 2050, Erwartete Auswirkungen auf Umwelt, Gesellschaft und Wirtschaft, Bern, 172 pp., 2007.

Rebetez, M., Lugon, R., and Baeriswyl, P.-A.: Climatic Change and debris Flows in High Mountain Regions: The Case Study of the Ritigraben Torrent (Swiss Alps), Clim. Change, 36, 371-389, 1997.

Regional Office of Carinthia, Department of Water Economy: Rainfall/Runoff Model for small catchment areas in the Lavant Valley for determination of potential future effects through assessment of regional climate change scenario. Interreg IIB Alpine Space project ClimChAlp - Climate Change, Impacts and Adaptation Strategies in the Alpine Space, Project report of WP 5 - Climate Change and Resulting Natural Hazards, Klagenfurt, 2008.

Schädler, B., Frei, C., Grebner, D., and Willi, H. P.: Grundlagen zum Klima, Wasser-Energie-Luft, 1, 58-59, 2007.

Stoll, C.: Schätzung des Schadenpotenzials bei Hochwasserereignissen durch die Ahr bei Uttenheim und St. georgen und durch die Rienz im Bereich Bruneck bis St. Lorenzen. Unpublished report for the Interreg IIIB project "River Basin Agenda", Bruneck, 80 pp., 2004.

Scherer, C. and Mazzorana, B.: Schutzwasserbau für den Oberen Eisack, Bericht zur Hydraulik. Unpublished report within the project Interreg IIIB Alpine Space "River Basin Agenda", Bozen, 66 pp., 2005a.

Scherer, C. and Mazzorana, B.: Schutzwasserbau für den Oberen Eisack. Bericht zur Hydrologie. Unpublished report within the project Interreg IIIB Alpine Space "River Basin Agenda", Bozen, 117 pp., 2005b.

Scherer, C. and Mazzorana, B.: Gefahrenszenarien im Einzugsgebiet des Mareiter Baches. Unpublished report within the project Interreg IIIB Alpine Space "ClimChAlp - Climate Change, Impacts and Adaptation Strategies in the Alpine Space”, Bozen, 129 pp., 2007.

Stötter, J.: Veränderungen der Kryosphäre in Vergangenheit und Zukunft sowie Folgeerscheinungen. Habilitation thesis, University of Munich, Munich, 264 pp., 1994.

Stötter, J. and Zischg, A.: Alpines Risikomanagement - theoretische Ansätze, erste Umsetzungen, in: Naturrisiken und Sozialkatastrophen, edited by: Felgentreff, C. and Glade, T., Berlin, Heidelberg, 297-310, 2007.

United Nations: Living with risk. United Nations, Geneva, 2004.

Villi, V. and Bacchi, B.: Valutazione delle piene nel Triveneto, CNR-GNDCI Consiglio nazionale delle ricerche - Gruppo nazionale per la difesa dalle catastrofi idrogeologiche, Padova, Brescia, 2001.

Zimmermann, M., Mani, P., and Gamma, P.: Murganggefahr und Klimaänderung - ein GIS-basierter Ansatz. vdf, Zurich, 161 pp. 1997.

Zimmermann, M. and Haeberli, W.: Climatic change and debris flow activity in high mountain areas: a case study in the Swiss Alps. Catena Supplement, 22, 59-72, 1992. 